\title{
TEACHING STRATEGY ON SPEAKING SKILLS TOWARD CELPAD IIUM STUDENTS
}

\author{
Siti Safura \\ sitisafura11@gmail.com \\ Universitas Muhammadiyah Aceh \\ Kholijah Asro \\ kholijah.asro@yahoo.com \\ International Islamic University of Malaysia
}

\begin{abstract}
Mastering a good strategy in teaching speaking constitutes one of the most important factors in teaching for educator. This is particularly so when student in other countries should speak English that basically is not his mother tongue. Good strategy in teaching speaking has been assumed as having a significant impact on students' speaking skill. This study addressed the application and influence of a teaching strategy toward speaking skill for students. This study was conducted to17 students at Level 6 Section 12 and one teacher at CELPAD of IIUM. This study utilized mixed method between quantitative and qualitative by collecting data through observation, questionnaires and interview. The findings indicate that discussion strategy applied by the teacher was effective to improve students speaking skills. Students were more interested and motivated in speaking English using discussion.
\end{abstract}

Keywords: teaching strategy, speaking skill, CELPAD, discussions

\section{INTRODUCTION}

No one denies the importance of English language in the present time as a global language. It is clear that the English language has become more dominant around the world. In some countries it is used as the mother tongue and in other countries it is established as a second language at schools. English is an important language for every country in the world, and it is also well-known in business, government, world news, and communication. One of the main reasons why the English is dominant at present time is that it is formally used in the field of education by universities and institutes as well as in scientific research. Hence, mastering English language is necessary for everybody all over the world.

English language has become easier to learn more than ever before with the availability of different sources to help people learn easily such as the Internet, e-books, and educational institutions which spread all over the world. Despite all of these tools, foreign students of English encounter many problems in terms of the four skills of learning this important language, especially speaking skill. Richards \& Renandya's (2002, 201) assert that large percentage of the world's language learners study English in order to develop proficiency in speaking. Speaking is the most important language skills that need to be controlled, and they assess learning achievement based on mastery of speaking skills (Burnkart, 1998). So, speaking is one of the skills which need to be mastered by the learners.

Some foreign students still encounter many problems in their English skill, especially speaking skill. These are caused by both internal problems and external problems. For internal problems, the students rarely understand and use English structure in the right way. The students are afraid of saying the other language which is not of their mother-tongue and 
they may be shy to speak it out. From these reasons, they seem to lack the practice of English language in daily activities. Therefore, their skills cannot be developed further.

For external problems, the students do not have a chance to study with the English native speakers when they were young. The situation of the English study is mostly ruled by their own language. It often forces students to take English tutorial courses. However, they have only a little time in classrooms to practice it. This may be the reason why the students of CELPAD (Centre of Language and PreUniversity Academic Development) of IIUM (International Islamic University of Malaysia) have poor level of proficiency in English language skills. Similarly, many researches have claimed that most of majors/graduates who join universities as English language majors or as English language learners have difficulties in using English for communication.

According to BO Smith (undated), teaching strategy refers to a pattern of teaching acts that serves to attain certain outcomes. Therefore, teachers have to adopt and adapt various methods in speaking classrooms to ensure that the students are excellent speaking. This article will discuss the influence of the teaching strategy in teaching speaking skill for students.

Many students are not able to speak English well because they seldom practice in their daily activities. In helping students to improve speaking skills, the teacher needs to use good strategy in their teachings. According to Bygate (1987), the problem in teaching a foreign language or a second language is to prepare the students to use the language.

Indeed, in CELPAD, it is a demanding task for teacher to provide the good strategy in teaching speaking skills for students. It leads into questions on what the teaching strategy on speaking applied by teacher in
CELPAD is and whether it influences students' speaking skill or not?

\section{LITERATURE REVIEW}

According to Orlich et. al. (1985) teaching strategies are intended for education-related courses dealing with instructional method or techniques, but it may be profitably used a reference book for a variety of other purposes.

In this study, a teaching strategy was need to apply in speaking skills. The skill of speaking is as crucial as any other language skills. Speaking is an interactive process of constructing meaning that involves producing and receiving and processing information (Brown 1994; Burns \& Joyce 1997). According to Theodore (1960, 5), speaking is a skill used by someone in daily life communication whether at school or outside.

From the definition above, it can be inferred that speaking is expressing, ideas, opinion, or feeling to other by using words or sounds of articulation in order to inform, to persuade, and to entertain that can be learnt by using some teaching-learning methodologies.

Faerch \& Kasper (in Brown 2000, 127) define speaking strategies as potentially conscious plans for solving what to an individual presents itself as a problem in reaching a particular communicative goal. They are also called compensatory strategies because L2 learners are always having to compensate for the limited vocabulary at their disposal (Cook 1996, 90).

According to Killen $(1998,2)$ there are many kinds of teaching strategies including:

1. Direct instruction, that is a variety of whole-class expository teaching techniques (sometimes less flatteringly called "chalk and talk")

2. Discussion, that is an orderly process of face to face group interaction in which people exchange ideals about an issue for the purpose of solving a problem, answering a question, enhancing 
their knowledge or understanding, or making a decision

3. Group work, when two or more students are working together or when the teacher is using whole class instruction

4. Cooperative learning, that is both an instructional technique and a teaching philosophy that encourages students to work together to maximize their own learning and the learning of their peers

5. Problem solving, that is a process of applying existing knowledge to a new or unfamiliar situation is order to gain new knowledge

6. Student research, that is using student research as a teaching strategy, you must decide why you want students to gather information, decide what you want student to gather information about, make it possible for them to gather it, help them to interpret the information they find, and respond to the conclusions they reach

7. Performance activity, which requires one or more students to 'act' a part.

However, there are some problems encountered in speaking skills. As Brown demonstrates some characteristics of spoken language that can make oral performance easy as well as in some cases difficult as follows:

1. Clustering

In spoken language, due to memory limitations and our predisposition for 'chunking' or clustering, we break down speech into smaller groups of words. In teaching listening comprehension, therefore, you need to help students to pick out manageable clusters of words

2. Redundancy

Spoken language has a good deal of redundancy (rephrasing, repetition, elaboration, and insertions of 'I mean' and 'You know'). Learners can train themselves to profit from it by first becoming aware of it and by looking for the its signals.
3. Reduced forms

Spoken language has many reduced forms and sentence fragments. Reduction can be phonological (Didju?), morphological (I'll), syntactic, or pragmatic (Mom! Phone!)

4. Performance variables.

In spoken language, hesitations, false starts, pauses, and corrections are common. There are also many ungrammatical forms and dialect differences

5. Colloquial language.

Idioms, slang, reduced forms, and shared cultural knowledge are all part of spoken language. Learners are usually exposed to 'textbook English' and need help

6. Rate of delivery

The number and length of pauses are more crucial to comprehension than sheer speed (Richards 1983). Still, learners need to be able to comprehend language delivered at varying rates of speed and, at times, delivered with few pauses

7. Stress, rhythm, and intonation

English is a stress-timed language. Also, intonation patterns are significant for interpreting questions, statements, emphasis, sarcasm, endearment, insult, solicitation, praise, etc.

8. Interaction

The spoken word is subject to rules of interaction: negotiation, clarification, attending signals, turntaking, and topic nomination, maintenance, and termination. To learn to listen is also to learn to respond and to continue a chain of listening and responding.

\section{MethodS}

The respondents of the study consisted of 17 students (5 females and 12 males) of Level 6 Section 12 at CELPAD of IIUM. A set of questionnaires were distributed to the students after the class activities. The students and teacher were observed as participants in the speaking activities. 
In this study, both qualitative and quantitative research methodology were utilized. There were three techniques of collecting the data, namely questionnaire, observation, and interview.

For the purpose of data collection, a set of questionnaire with 20 Likertscale questions and Yes/No questions were designed. This questionnaire was designed to gather the students' opinions to improve their speaking skills. This questionnaire consisted two sections that was section $\mathrm{A}$ and section B. In section A, the students were required to answer the questions by circling the appropriate scales to determine their awareness on speaking skills. In section $\mathrm{B}$, the students were required to answer the questions by ticking $(\sqrt{ })$ the answer to recognize the teacher's strategy.

Observation was another research instrument to examine the students' participation and teacher's strategy in the class. The observation provided immediate information needed in this study and the students' behaviors while engaging in the observed activities. Two observations were conducted, in which the researcher focused on students' communication in English, and teacher's strategy in improving the skills. The target students and teacher's strategy were observed in two different observations in 90 minutes. The overall participation was then recorded on the observation sheet.

Interview was conducted with one English teacher after the class. The interview was semi-structured whereby ten questions were prepared before the interview and some additional questions were asked on the spot. There are 10 relevant questions to gather information and support the results obtained from the questionnaires and observations. According to Moser and Kalton (1971), interview is described as a means of eliciting relevant information and personal opinion from the respondents.

\section{FINDINGS}

The followings are the research process and findings resulted from the three technique of data collections, i.e.: questionnaires, observation and interviews and data analysis.

\section{Questionnaires}

In the first section of questionnaires, students were given the following 20 statements to respond to about their speaking strategies:

1. If I do not know how to say a word or phrase, I ask a classmate or my teacher.

2. I use English to English dictionary to improve my pronunciation and learn new words

3. If I do not know how to say a word, I use a synonym or describe what I want to say.

4. I tell my speaking partner when I do not understand something.

5. If I do not know how to say a word in English, I say it in my own language

6. If I do not know how to say a word or phrase, I use gestures and my hands.

7. I ask my speaking partner to repeat a word or phrase if I do not hear it clearly.

8. When my friends speak in class, I try to check their errors and correct them mentally

9. I structure some ideas in my mind before speaking.

10. To gain time, I use fillers such as: and, well, emm, yeah, etc.

11. I repeat the last word or phrase I said to gain time.

12. I am worried about making mistakes and I feel shy when I make a mistake

13. I do not think too much before speaking so that ideas can flow in English.

14. I ask my speaking partner to repeat or explain in different words what I did not understand.

15. If I have time, first I write, and then I speak 
16. I read newspaper and books in order to learn structure and word

17. I speak English with my teacher and friends after class.

18. I watch movies or TV programs in English to improve my speaking ability
Table 1 shows that the students who never spoke in their own language when they did not know how to say a word in English were $47 \%$. In addition, there were about $52.9 \%$ of students who sometimes chose not to think too much in their speaking so that their

Table 1: Students Speaking Strategies

\begin{tabular}{|c|c|c|c|c|}
\hline $\begin{array}{l}\text { Question } \\
\text { Number }\end{array}$ & 1 & 2 & 3 & 4 \\
\hline 1 & $11.7 \%$ & $23.5 \%$ & $41 \%$ & $23.5 \%$ \\
\hline 2 & $0 \%$ & $47 \%$ & $29.4 \%$ & $23.5 \%$ \\
\hline 3 & $5.8 \%$ & $17.6 \%$ & $35.2 \%$ & $41 \%$ \\
\hline 4 & $11.7 \%$ & $29.4 \%$ & $35 \%$ & $23.5 \%$ \\
\hline 5 & $47 \%$ & $29.4 \%$ & $35 \%$ & $23.5 \%$ \\
\hline 6 & $17.6 \%$ & $35 \%$ & 29.4 & $11.7 \%$ \\
\hline 7 & $5.8 \%$ & $11.7 \%$ & $47 \%$ & $35 \%$ \\
\hline 8 & $5.8 \%$ & $47 \%$ & $35 \%$ & $5.8 \%$ \\
\hline 10 & $11.7 \%$ & $35 \%$ & $41 \%$ & $11.7 \%$ \\
\hline 11 & $23.5 \%$ & $41 \%$ & $35 \%$ & $0 \%$ \\
\hline 12 & 23.5 & $23.5 \%$ & $29.4 \%$ & $23.5 \%$ \\
\hline 13 & $23.5 \%$ & $52.9 \%$ & $17.6 \%$ & $5.8 \%$ \\
\hline 14 & $5.8 \%$ & $41 \%$ & $41 \%$ & $11.7 \%$ \\
\hline 15 & $41 \%$ & $11.7 \%$ & $23.5 \%$ & $23.5 \%$ \\
\hline 16 & $17.6 \%$ & $41 \%$ & $29.4 \%$ & $11.7 \%$ \\
\hline 17 & $5.8 \%$ & $29.4 \%$ & $41 \%$ & $23.5 \%$ \\
\hline 18 & $5.8 \%$ & $23.5 \%$ & $35 \%$ & $35 \%$ \\
\hline 19 & $5.8 \%$ & $41 \%$ & $41 \%$ & $11.7 \%$ \\
\hline 20 & $5.8 \%$ & $23.5 \%$ & $47 \%$ & $23.5 \%$ \\
\hline
\end{tabular}

19. When my teacher asks questions in class, I try to answer him/her mentally to myself.

20. When listening to my teachers or people who are good at English, I am careful about the structures, words and idioms that they use, and I try to use them in my speech.

The students were given four options to respond to the statements, i.e: (1) almost never, (2) sometimes, (3) quite frequently, (4) almost always. The result of the questionnaire can be seen in Table 1. ideas could flow smoothly in English. Meanwhile, the students who quite frequently asked for repetition to their partners in speaking when it was not clear as well as listened carefully to their teacher's speaking to be used in their speeches were around $47 \%$. In addition, the students who almost always used synonyms of words they did not know in English were as much as $41 \%$ of the total respondents. Thus, as can be seen from the table, the students generally try to improve their speaking abilities. 
In the second section, students dealt with four propositions to evaluate the teaching strategies applied by the teacher as follow:

1. The teacher uses some strategies in speaking skills (discussion, debate, etc)

2. The strategy is effective to improve my speaking ability

3. The teacher has good interaction with the students

4. The instruction of teacher is clear

There were three different responses available to choose, namely: Yes, Not sure, and No. The results of the questionnare can be seen in Table 2 . activities. The questions which had to be checked Yes or No are as follow:

1. Is the teacher begins the class well (greeting, introduction)?

2. Does the teacher give motivation?

3. Does the teacher organize an effective lesson (planning, sequence, appropriate, engaging, etc)?

4. Does the teacher use the strategy in speaking class?

5. Does the teacher apply the strategy well?

6. Are students active in the class?

7. Does everyone speak in the class?

8. Does the teacher ask silent students to talk?

Table 2: Teacher Teaching Strategy

\begin{tabular}{cccc}
\hline $\begin{array}{c}\text { Question } \\
\text { Number }\end{array}$ & Yes & Not sure & No \\
\cline { 1 - 2 } $\mathbf{1}$ & $76.4 \%$ & $23.5 \%$ & $0 \%$ \\
$\mathbf{2}$ & $82 \%$ & $17.6 \%$ & $0 \%$ \\
$\mathbf{3}$ & $94 \%$ & $0 \%$ & $5.8 \%$ \\
$\mathbf{4}$ & $94 \%$ & $5.8 \%$ & $0 \%$ \\
\hline
\end{tabular}

Table 2 shows the highest percentage of the students who choose to answer Yes in the second part of the questionnaire. For item number 3 (The teacher has good interaction with the students) and number 4 (The instruction of teacher is clear), there were approximately $\quad 94 \% \quad$ students. Meanwhile, the lowest percentage of students who selected the answer No lies in item number 1 (The teacher uses some strategies in speaking skills: discussion, debate, etc), number 2 (The strategy is effective to improve my speaking ability) and number 4 (The instruction of teacher is clear) at $0 \%$. In conclusion, it can be seen that the strategy that the teacher applied was effective for the students, particularly in speaking skills.

\section{Observation}

In observation, there are 10 questions about the teacher's strategy and students' participation in speaking
9. Is the teacher able to provide his/her Students with more opportunities to talk?

10. Does the teacher conclude the lesson?

From the observation, we found that the teacher used an effective strategy named discussion through which he/she gave motivations to the students by asking question. It made student involved actively in speaking. Teacher provided every student, especially the passive ones, to talk in the classroom. In addition, the way the teacher delivered the explanation was clear and fun so that the students were interested to speak. However, in managing the class, the teacher did not organize an effective lesson such in planning, sequence, appropriate, engaging, etc. It was proven when the teacher did not start and conclude the lesson properly.

\section{Interview}

In the interview, there were also 10 questions asked to the teacher as the 
counterpart of questionnaires and observation to the students. The questions can be seen below:

1. How many years, you have been teaching in CELPAD?

2. How do you diagnose your students' needs in speaking?

3. What would you do to help nonEnglish speaking students feel comfortable at the classroom and to achieve their speaking skills?

4. What are the strategies that you often use in speaking activity?

5. Do you think those strategies are effective?

6. Are the students actively involved when you are taking speaking lesson?

7. Are you often bring the additional material in the classroom, such as video?

8. How do you manage your speaking classroom?

9. How do you assess your students in speaking skill?

10. How do you handle the different ability levels of students in your speaking classroom?

From the interview, it is found that the teacher diagnosed the students needs by identifying the strengths and the weaknesses of the students. It was important to know the students needs to determine the action given to fulfill them. In addition, Encouragement and motivation were two other important things to boost students' spirits to speak English in the classroom and outside it. Teacher had to concern toward students attitude and took the action needed toward active and passive students in the classroom. To enhance vocabulary and idea to speak, teacher encouraged students to read a lot. Lacking vocabulary and information would affect in students' abilities in delivering information.

Furthermore, information and knowledge were the key to elaborate the idea in speaking. To be active in speaking, students had to possess both and familiar with the topic of discussion. Discussion was one of strategy to encourage passive students to speak up their ideas. It was a good way by which the students could share their opinions in a group for the other member to correct. Good relationship and knowing each other was one of solution for passive students to get confidence in delivering their opinions. In this case, the students' skills in speaking were measured by EPT (English Placement Test) results. The teacher also assessed the students' speaking skills from their performance in the classroom.

\section{Conclusions AND SugGestions}

Based on the result of the study, it is found that the discussion teaching strategy that the teacher applied in the classroom had significantly influenced the improvement of students' speaking skills at CELPAD of IIUM. It was proven from the results of questionnaire which showed that discussion is an effective strategy for speaking activities in the classroom. Meanwhile, the results of the observation and interview showed that the students were more interested and motivated in speaking English from the discussion activities.

Thus, it is suggested that English teachers, particularly at CELPAD, use discussion for teaching students, in order to overcome the problem in speaking and improve students' skills in it. It is also suggested to other researchers to conduct other research about improving other skills in English through discussion to complete this research result.

\section{REFERENCES}

Al-Harrasi, SM. 2001. "English language learners' use of speaking strategies, Teacher of English". Batinah South Regio, 18

Brown, HD. 1994. Principle of Language Learning And Teaching. New York: Prentice

Hall

Fauziah. 2012 Teaching Speaking Using Cooperative Learning Strategy At 
SeventhClass Students of MTs AlLuthfah Cililin. http://publikasi. stkipsiliwangi.ac.id/files/2012/09/082202 41-Fauzia.pdf. Accessed on April 27, 2013

Hamzam, MH \& Ting, LY. Teaching Speaking Skills Through Group Work Activities: A Case Study in SMK Damai Jaya. Retrieved on 27 April 2013. www.eprint.utm.my/10255/2/Lu_Yee_Ti ng.pdf
Khameis, Mona. 2006. Using Creative Strategies to Promote Students' Speaking Skills. Accessed on April 2013, 27 http://marifa.hct.ac.ae/files/2011/07/Usi ng-Creative-Strategies-to-PromoteStudents-Speaking-Skills.pdf

Nazara, Situjuh. 2011. "Students' Perception on EFL Speaking Skill Development". Journal of English Teaching 1 (1): 28-41 